\title{
Pulmonary adenocarcinoma with osseous metaplasia: a rare occurrence possibly associated with early stage?
}

This article was published in the following Dove Press journal:

OncoTargets and Therapy

8 November 2013

Number of times this article has been viewed

\author{
Qingfu Zhang' \\ Liying Yin ${ }^{2}$ \\ Bo $\mathrm{Li}^{3}$ \\ Rui Meng ${ }^{4}$ \\ Runa Dao' \\ Suxiang $\mathrm{Hu}^{3}$ \\ Xueshan Qiu' \\ 'Department of Pathology, The First \\ Affiliated Hospital and College of \\ Basic Medical Sciences, China Medical \\ University, Shenyang, ${ }^{2}$ Department \\ of Pathology, No 5 People's Hospital, \\ Dalian, ${ }^{3}$ Shengjing Hospital of \\ China Medical University, Shenyang, \\ ${ }^{4}$ Department of Gerontology, \\ Aerospace Central Hospital, Beijing, \\ People's Republic of China
}

\begin{abstract}
Adenocarcinoma is the most common type of malignant pulmonary tumor, but osseous metaplasia of this tumor is extremely rare. To date, only 21 cases have been reported in the literature worldwide. Here, we report a case of primary pulmonary adenocarcinoma with benign osseous stromal metaplasia in a 60-year-old woman and discuss the pathogenesis of intratumoral ossification and review the relevant literature. We found that pulmonary adenocarcinoma with osseous metaplasia may be more likely to occur in early tumor stages.
\end{abstract}

Keywords: pulmonary adenocarcinoma, immunohistochemistry, osseous metaplasia

\section{Introduction}

Metaplasia is a process in which a differentiated cell type is replaced by another mature differentiated cell type. Although rare, osseous stromal metaplasia has been described in the literature for both benign and malignant neoplasms. Here, we report a unique case of primary pulmonary carcinoma with osseous metaplasia. We believe that this is a case of minimum bone formation (approximately $1.25 \mathrm{~mm} \times 0.85 \mathrm{~mm}$ ) in a primary pulmonary carcinoma.

\section{Case report}

A 60-year-old Chinese woman presented with the symptom of bloody sputum, which she had noticed for 2 weeks. Enhanced computed tomography (CT) showed an irregular abnormal soft tissue mass located in the left upper lobe that was approximately $1.7 \mathrm{~cm} \times 0.8 \mathrm{~cm}$ in size and obviously enhanced with contrast medium (Figure 1). The CT value in the enhanced arterial phase was approximately 40-60 Hounsfield units, while the venous phase CT value was approximately 72 Hounsfield units. Minimal calcification was not apparent in the tumor. The patient denied any history of gastric carcinoma or digestive symptoms. On the basis of her history and imaging studies, the patient was diagnosed with a malignant pulmonary tumor and underwent lobectomy. The tumor had a heterogeneous off-white appearance and was solid with unclear boundaries. No depressions or varicose veins were found in the pleura.

Hematoxylin and eosin-stained sections showed that the alveolar structure had disappeared within the tumor and that the tumor cells were distributed into round or oval glands with a central lumen. There was no mucin in the tumor cell cytoplasm or glandular cavity. The tumor cell nuclei were ovoid and dark-stained, with prominent nucleoli. The mitotic activity was approximately two mitoses per ten high-powered fields. New bone formation was observed at the center of the tumor (approximately
Correspondence: Xueshan Qiu Department of Pathology, The First Affiliated Hospital and College of Basic Medical Sciences, China Medical University, Shenyang, People's Republic of China Email cmupathology@।63.com 


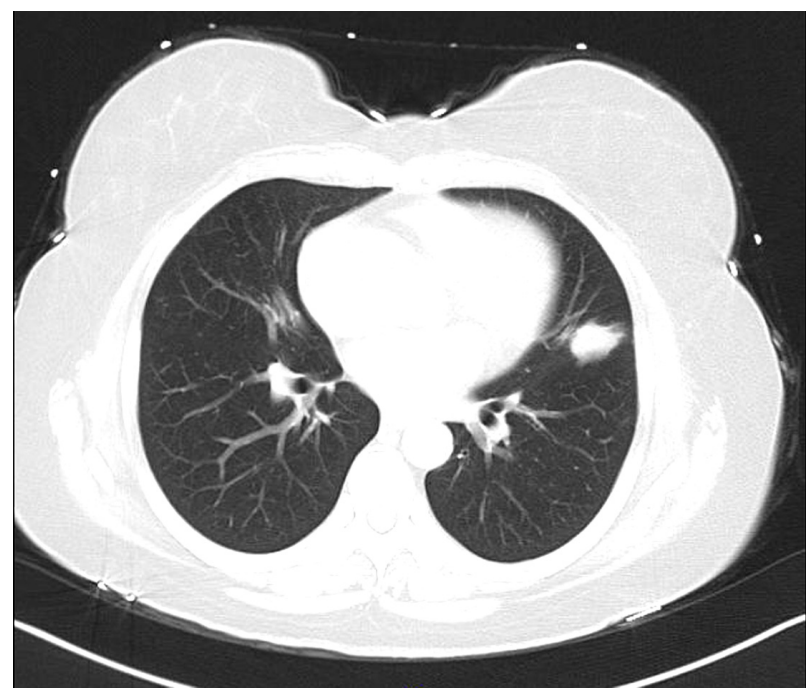

Figure I Computed tomography scan showed an irregular abnormal soft tissue mass located in the left upper lobe.

$1.25 \mathrm{~mm} \times 0.85 \mathrm{~mm}$, Figure $2 \mathrm{~A})$. The bone island consisted of mature bone tissue and was surrounded by osteoblast cells that were accompanied by proliferating fibroblasts (Figure 2B). No bone marrow cells were present in the bone tissue. Immunohistochemical staining showed that the tumor cells were positive for cytokeratin-7 (Figure 3A) and thyroid transcription factor-1 (Figure 3B), but the metaplastic bone tissue was negative for these factors. However, the tumor cells were negative for caudal-related homeodomain protein 2, which ruled out the possibility of gastrointestinal adenocarcinoma metastasis to the lung, and the Ki-67 labeling index was approximately 35\%. An epidermal growth factor receptor exon 19 deletion mutation was found in this patient, but the echinoderm microtubule-associated proteinlike 4-anaplastic lymphoma kinase rearrangement was not found. On the basis of histologic and immunohistochemical findings, this tumor was diagnosed as an invasive pulmonary adenocarcinoma with a predominant acinar pattern, accompanied by osseous metaplasia in tiny lesions and without lymphatic metastasis. This diagnosis was based on

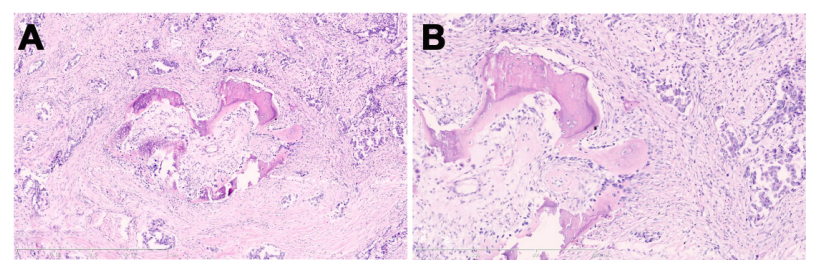

Figure 2 (A) Tumor showing the moderately differentiated adenocarcinoma growing with a born formation. Hematoxylin and eosin staining, original magnification $\times 50$. Scale bar I mm. (B) Mature bony trabeculae in the abundant fibroblastic stroma were surrounded by osteoblasts. Hematoxylin and eosin staining, original magnification $\times 100$. Scale bar $600 \mu \mathrm{m}$.

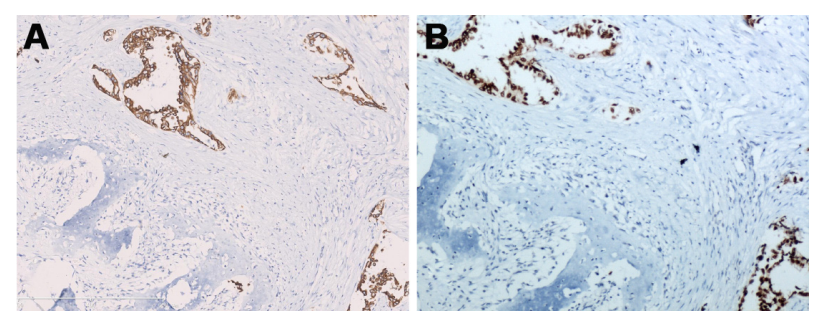

Figure 3 (A) On immunohistochemical analysis, tumor cells were positive for cytokeratin 7. (B) TTF-I immunohistochemistry shows strong nucleus staining in the tumor cells, original magnification $\times 100$. Scale bar $400 \mu \mathrm{m}$.

Abbreviation: TTF-I, thyroid transcription factor-I.

the International Association for the Study of Lung Cancer/ American Thoracic Society/European Respiratory Society classification system for standard lung adenocarcinoma. ${ }^{1}$

\section{Discussion}

Malignant neoplasms accompanied by osseous metaplasia have been sporadically reported in the kidney, ${ }^{2}$ gastrointestinal tract, ${ }^{3,4}$ thyroid, ${ }^{5}$ soft tissue, ${ }^{6}$ endometrium, ${ }^{7}$ bladder, ${ }^{8}$ brain, ${ }^{9}$ and urachus $;^{10}$ however, heterotopic ossification within a primary pulmonary carcinoma is extremely rare. Only 21 cases of pulmonary adenocarcinoma with heterotopic ossification have been previously reported ${ }^{11-22}$ in patients whose ages ranged from 46 to 76 (mean 62.4) years. The male to female ratio in these patients was 11:10, and the tumor sizes ranged from $1.5 \mathrm{~cm}$ to $7 \mathrm{~cm}$ (mean $3.59 \mathrm{~cm}$ ). One patient received radiotherapy. Two patients also presented with osteoplastic metastasis. Follow-up information was available for 14 patients and indicated that one patient died after 33 months, while one patient developed a recurrence after 60 months of follow-up. In contrast with patients having conventional lung adenocarcinoma, which usually presents as an advanced cancer, ${ }^{23}$ lung adenocarcinoma with osseous metaplasia seems to be more frequent in early-stage disease, given that patients with stage I, II, III, and IV disease accounted for $57.1 \%(n=12), 14.3 \%(n=3), 19.0 \%(n=4)$, and $4.8 \%(n=1)$ of the cases, respectively; staging information was not available for one patient. The stage of the patient presented in this paper was IA, which is consistent with this phenomenon (Table 1).

The mechanism responsible for osseous histogenesis in malignant neoplasms remains obscure. Several studies have documented that osseous metaplasia results from osteoblast metaplasia of pulmonary fibroblasts. ${ }^{22}$ Other studies reported abnormally high serum calcium levels (hypercalcemia) in patients with malignant neoplasms; these levels were closely associated with bone formation. However, the serum calcium level was within normal limits in this patient. Most authors report that multipotent stromal stem cells are involved in 
Table I Summary of previously reported cases of heterotopic mesenteric ossification

\begin{tabular}{|c|c|c|c|c|c|c|c|c|}
\hline Reference & Sex/age & Size $(\mathrm{cm})$ & Histological type & P stage & TNM & Operation & CT/RT & Follow-up \\
\hline McLendon et al" & $M / 62$ & 3 & Adeno/mod & IIIA & TIN2M0 & Lob & NA & NA \\
\hline Yoshida et $\mathrm{al}^{13}$ & $M / 49$ & 3.5 & Adeno/mod & IIB & T2NIMO & Lob & NA & Recur, 60 months \\
\hline Miyata et al ${ }^{12}$ & $\mathrm{~F} / 62$ & 3.3 & Adeno/well & IB & T2NOMO & Lob & NA & NA \\
\hline Fukuse et al ${ }^{14}$ & $M / 6 I$ & 4.5 & Adeno/mod & IB & T2NOMO & Lob & NA & NA \\
\hline Hayakawa et al ${ }^{15}$ & $M / 53$ & NA & Adeno/mod & IV & $\mathrm{T} ? \mathrm{~N} 2 \mathrm{MI}$ & Autopsy & $\mathrm{RT}$ & Dead, 33 months \\
\hline Tsuchiya et al ${ }^{18}$ & $\mathrm{~F} / 70$ & NA & NA & IA & TINOMO & Lob & NA & NA \\
\hline Hara et $\mathrm{al}^{16}$ & $\mathrm{~F} / 70$ & 3.2 & Adeno/mod & IIIB & $\mathrm{T} 4 \mathrm{~N} 2 \mathrm{MO}$ & Lob & NA & Alive, 6 months \\
\hline Hosoda et $\mathrm{al}^{17}$ & $M / 66$ & 3 & Adeno/mod & $\mathrm{IA}$ & TINOMO & Lob & NA & NA \\
\hline Usami et $\mathrm{a}^{20}$ & $M / 46$ & 4.5 & Adeno/poor & IB & T2NOMO & Lob & NA & Alive, 14 months \\
\hline Ueshima et al ${ }^{19}$ & $\mathrm{~F} / 73$ & NA & NA & NA & NA & Lob & NA & NA \\
\hline Kato et $\mathrm{al}^{2 !}$ & $M / 76$ & 1.5 & NA & IA & TINOMO & Lob & NA & NA \\
\hline Kim et $\mathrm{al}^{22}$ & $F / 65$ & 3.2 & Adeno/mod & IB & T2NOMO & Lob & NA & Alive, 52 months \\
\hline Kim et $\mathrm{al}^{22}$ & $M / 70$ & 4 & Adeno/mod & IIB & T2NIMO & Bilob & $\mathrm{CT}$ & Alive, 49 months \\
\hline Kim et $\mathrm{al}^{22}$ & $M / 63$ & 3.7 & Adeno/mod & IB & T2NOMO & Lob & CT & Alive, 43 months \\
\hline Kim et $\mathrm{al}^{22}$ & $\mathrm{~F} / 65$ & 6 & Adeno/mod & IB & T2NOMO & Lob & NA & Alive, 27 months \\
\hline Kim et $\mathrm{al}^{22}$ & $M / 57$ & 4.5 & Adeno/mod & IB & T2NOMO & Lob & NA & Alive, 14 months \\
\hline Kim et $\mathrm{al}^{22}$ & $\mathrm{~F} / 66$ & 2 & Adeno/poor & IIA & TINIMO & Lob & CT & Alive, 13 months \\
\hline Kim et $\mathrm{al}^{22}$ & $F / 57$ & 7 & Adeno $/ \mathrm{mod}$ & IIIA & $\mathrm{T} 2 \mathrm{~N} 2 \mathrm{MO}$ & Lob & CT & Alive, 12 months \\
\hline Kim et $\mathrm{al}^{22}$ & $\mathrm{~F} / 57$ & 2.5 & Adeno/mod & $\mathrm{IA}$ & TINOMO & Lob & NA & Alive, 10 months \\
\hline Kim et $\mathrm{al}^{22}$ & $M / 59$ & 2.5 & Adeno/mod & IIIB & T4NOMO & Lob & CT & Alive, 4 months \\
\hline Kim et $\mathrm{al}^{22}$ & $\mathrm{~F} / 64$ & 2.8 & Adeno/mod & $\mathrm{IB}$ & T2NOMO & Lob & NA & Alive, 4 months \\
\hline Present case & $F / 60$ & 1.7 & Adeno/mod & $\mathrm{IA}$ & TINOMO & Lob & NA & Alive, 26 months \\
\hline
\end{tabular}

Abbreviations: Adeno, adenocarcinoma; mod, moderately differentiated; well, well differentiated; NA, not available; Bilob, bilobectomy of right middle and lower lobe; Lob, lobectomy; CT, chemotherapy; Recur, recurrence; RT, radiation therapy.

the metaplastic process, resulting in bone formation. ${ }^{24}$ Some cytokines such as bone morphogenetic protein 7 promote bone formation by inducing differentiation of pluripotent cells, mesenchymal cells, or fibroblasts into osteoprogenitor cells. ${ }^{25}$ Further, some studies showed that bone formation might occur as a result of local or systemic inflammation. Inflammatory cells, including monocytes and macrophages, produce cytokines such as tumor necrosis factor-alpha and interleukin-1. Tumor necrosis factor-alpha and interleukin-1 are reported to stimulate activated cells to produce transforming growth factor beta and bone morphogenetic protein 7 , which act as local cellular regulators of ectopic bone formation. ${ }^{26,27}$

Osseous histogenesis in malignant neoplasms is a rare and interesting phenomenon, but the prognostic implications of this occurrence are not very clearly described in the literature. Some studies suggest that cerebral ventricle ependymoma with ossification might exhibit more aggressive clinical behavior. ${ }^{9}$ However, ossification has been suggested to be a marker of favorable prognosis in patients with renal cell carcinoma. ${ }^{28}$ Therefore, investigations of the prognosis in patients with pulmonary adenocarcinoma and bone formation remain worthwhile. The lack of evidence of recurrence and metastasis in this patient at a 26-month follow-up indicated that ossification in pulmonary adenocarcinoma might not have adverse prognostic implications, but a longer follow-up period and more case studies are needed to illustrate this rare phenomenon.

\section{Disclosure}

The authors report no conflicts of interest in this work.

\section{References}

1. Warth A, Muley T, Meister M, et al. The novel histologic International Association for the Study of Lung Cancer/American Thoracic Society/ European Respiratory Society classification system of lung adenocarcinoma is a stage-independent predictor of survival. J Clin Oncol. 2012;30: $1438-1446$

2. Puppa G, Gervasio A, Yorukoglu K, Colombari R, De Marchi F, Canzonieri V. Huge renal cyst with parietal renal cell carcinoma, osseous metaplasia and a papillary adenoma: a case report with unique clinicopathological features and literature review. Virchows Arch. 2008;452: 325-330.

3. Wilsher MJ. Adenocarcinoma arising in a traditional serrated adenoma of the rectosigmoid colon with osseous metaplasia. Pathol Int. 2011;61: 239-242.

4. Zapata E, Castiella A, Zubiaurre L, Agirre A, Rodriguez J. Osseous metaplasia in a gastric adenomatous polyp. Endoscopy. 2012;44:E81.

5. Pontikides N, Botsios D, Kariki E, Vassiliadis K, Krassas GE. Extramedullary hemopoiesis in a thyroid nodule with extensive bone metaplasia and mature bone formation. Thyroid. 2003;13:877-880.

6. Orui H, Ishikawa A, Tsuchiya T, Takahara M, Ito M, Ogino T. Chondroosseous differentiation in fat tissue tumors: magnetic resonance imaging with pathological correlation. Skeletal Radiol. 2000;29:459-465.

7. Parente RC, Patriarca MT, de Moura Neto RS, et al. Genetic analysis of the cause of endometrial osseous metaplasia. Obstet Gynecol. 2009;114: 1103-1108.

8. Dudley AG, Tomaszewski JJ, Hughes AH, Davies BJ. Incidentally discovered osseous metaplasia within high-grade urothelial carcinoma of the bladder. Urology. 2012;79:e59-e60. 
9. Wang X, Zhang S, Ye Y, Chen Y, Liu X. Ependymoma with cartilaginous metaplasia might have more aggressive behavior: a case report and literature review. Brain Tumor Pathol. 2012;29:172-176.

10. Lopez-Beltran A, Nogales F, Donné CH, Sayag JL. Adenocarcinoma of the urachus showing extensive calcification and stromal osseous metaplasia. Urol Int. 1994;53:110-113.

11. McLendon RE, Roggli VL, Foster WL Jr, Becsey D. Carcinoma of the lung with osseous stromal metaplasia. Arch Pathol Lab Med. 1985;109: 1051-1153.

12. Miyata S, Nakagawa T, Maeda S, Miwa A, Kitagawa M, Takashima T. A case of adenocarcinoma of the lung with calcification on chest CT. Jpn J Lung Cancer. 1988;28:107-111.

13. Yoshida K, Morinaga S, Gemma A, Shimosato Y, Tsuchiya R, Eguchi K. Adenocarcinoma with stromal bone metaplasia of the lung. Jpn J Lung Cancer. 1988;28:87-92.

14. Fukuse T, Koh T, Okumura N, Kuwabara M, Suzuki Y. A case of primary lung cancer with stromal ossification. Jpn J Lung Cancer. 1990;30:267-272.

15. Hayakawa K, Murata O, Ishizeki K, et al. A case of pulmonary ossified adenocarcinoma with marked osteoplastic bone metastasis. Lung Cancer. 1997;18:265-268.

16. Hara H, Iwabuchi K, Shinada J, Yoshimura H, Kameya T. Pulmonary adenocarcinoma with heterotopic bone formation. Pathol Int. 2000;50: 910-913.

17. Hosoda H, Izumi H, Atarashi K, Shinohara N, Sunamori M. Lung adenocarcinoma with stromal ossification. Jpn J Lung Cancer. 2002;42: 51-54.

18. Tsuchiya T, Nishimura Y, Funada Y, et al. [Pulmonary adenocarcinoma with central ossification]. Nihon Kokyuki Gakkai Zasshi. 2000;38: 283-287. Japanese.

19. Ueshima Y, Kurioka H, Yamada R, Takumi C, Hiraoka N, Ono S. [Stromal bone formation by lung adenocarcinoma]. Nihon Kokyuki Gakkai Zasshi. 2005;43:523-526. Japanese.
20. Usami N, Yoshioka H, Mori S, Imaizumi M, Nagasaka T, Ueda Y. Primary lung adenocarcinoma with heterotopic bone formation. Jpn J Thorac Cardiovasc Surg. 2005;53:102-105.

21. Kato F, Iwasaki A, Miyoshi T, et al. A case of primary adenocarcinoma of the right lung with ossification. Journal of the Japanese Association for Chest Surgery. 2006;20:856-859.

22. Kim GY, Kim J, Kim TS, Han J. Pulmonary adenocarcinoma with heterotopic ossification. J Korean Med Sci. 2009;24:504-510.

23. Crinò L, Weder W, van Meerbeeck J, Felip E; ESMO Guidelines Working Group. Early stage and locally advanced (non-metastatic) non-small-cell lung cancer: ESMO Clinical Practice Guidelines for diagnosis, treatment and follow-up. Ann Oncol. 2010;21:103-115.

24. Xie L, Zhang N, Marsano A, Vunjak-Novakovic G, Zhang Y, Lopez MJ. In vitro mesenchymal trilineage differentiation and extracellular matrix production by adipose and bone marrow derived adult equine multipotent stromal cells on a collagen scaffold. Stem Cell Rev. July 28, 2013. [Epub ahead of print].

25. Toyran S, Lin AY, Edward DP. Expression of growth differentiation factor-5 and bone morphogenic protein-7 in intraocular osseous metaplasia. Br J Ophthalmol. 2005;89:885-890.

26. Dayer JM. Evidence for the biological modulation of IL-1 activity: the role of IL-1 Ra. Clin Exp Rheumatol. 2002;20:14-20.

27. Chao CC, Hu S, Sheng WS, Tsang M, Peterson PK. Tumor necrosis factor-alpha mediates the release of bioactive transforming growth factor-beta in murine microglial cell cultures. Clin Immunol Immunopathol. 1995;77:358-365.

28. Bielsa O, Lloreta J, Arango O, Serrano S, Gelabert-Mas A. Bone metaplasia in a case of bilateral renal cell carcinoma. Urol Int. 2001;66:55-56.
OncoTargets and Therapy

\section{Publish your work in this journal}

OncoTargets and Therapy is an international, peer-reviewed, open access journal focusing on the pathological basis of all cancers, potential targets for therapy and treatment protocols employed to improve the management of cancer patients. The journal also focuses on the impact of management programs and new therapeutic agents and protocols on

\section{Dovepress}

patient perspectives such as quality of life, adherence and satisfaction The manuscript management system is completely online and includes a very quick and fair peer-review system, which is all easy to use. Visit http://www.dovepress.com/testimonials.php to read real quotes from published authors. 